\title{
PERSEPSI MANAJEMEN BANK UMUM SYARIAH TERHADAP KEMUNGKINAN PENERAPAN PER (PROFIT EQUALIZATION RESERVE) DITINJAU DARI SISI AKUNTANSI BANK SYARIAH
}

\section{PERCEPTION MANAGEMENT OF ISLAMIC BANKS OF THE POSSIBILITY OF APPLICATION PER (PROFIT EQUALIZATION RESERVE) VIEWED FROM THE ISLAMIC BANK ACCOUNTING}

\author{
Nurlaela Syahril Barokah'ia, Afiati Kurniasih ${ }^{2 b}$ \\ 1aJurusan Ekonomi Islam Fakultas Perbankan Syariah Universitas Djuanda, Jl. Tol Ciawi No. 1, Bogor Kode Pos \\ 16720. \\ 2bJurusan Perbankan Syariah Fakultas Ekonomi Islam Universitas Djuanda, Jl. Tol Ciawi No. 1, Bogor Kode Pos \\ 16720 \\ Email : ${ }^{1 a}$ ling94.1a@gmail.com, 2b afiati_kurniasih@yahoo.com
}

(Diterima oleh Dewan Redaksi: Agustus)

(Dipublikasikan oleh Dewan Redaksi: Desember)

\begin{abstract}
The purpose of this study is to notice the perception of Public Syariah Bank management toward possible application of PER viewed from Syariah Bank accounting. The method used in this study is Miles Model and Huberman, which is with the way of data reduction, data display and conclusion drawing. Syariah Banks, in the effort of collecting and distributing fund with the use of mudharabah contract, should look deeply at appropriate strategy to prevent risk.

In mudharabah contract, gaining profit is fluctuative (never remains in one state). Therefore, there are plans to apply PER. The result of study shows that perception of Public Syariah Bank management; Muamalat Bank and Mandiri Syariah Bank branch of Bogor are ready to apply PER if it is indeedly needed and there are constitutions regulating and requiring the use of PER instrument. BMI and BSM branch of Bogor assumed that noting of PER to the system of accounting of Syariah Banks can be saved in white ballance (neraca pasiva) in post of KSD (obligation paid soon), detained profit, tied investment fund, and PPAP (Allowance for Uncollectible) or CKPN (Allowance for Impairment Losses).
\end{abstract}

Keywords: Profit Equalization Reserve, Mudharabah Contract.

\section{ABSTRAK}

Penelitian ini bertujuan untuk mengetahui persepsi manajemen bank umum syariah terhadap kemungkinan penerapan PER (Profit Equalization Reserve) ditinjau dari sisi akuntansi bank syariah. Metode yang digunakan adalah model Miles and Huberman, yaitu dengan cara data reduction, data display dan conclusing drawing. Bank syariah dalam melakukan usaha menghimpun dan menyalurkan dana dengan menggunakan akad mudharabah, dituntut agar selalu memperhatikan strategi yang tepat dalam mencegah terjadinya risiko.

Pada akad Mudharabah, perolehan keuntungan bersifat tidak tetap atau fluktuatif, oleh karena itu muncul wacana untuk menerapkan PER. Hasil penelitian menunjukkan bahwa persepsi manajemen Bank Umum Syariah (BUS) Bank Muamalat dan Bank Syariah Mandiri (BSM) cabang Bogor siap untk menerapkan PER jika memang diperlukan dan ada undangundang yang mengatur serta mengharuskan untuk menggunakan instrumen PER. BMI dan 
BSM cabang Bogor mengasumsikan pencatatan PER pada sistem akuntansi bank syariah bisa disimpan pada neraca pasiva di pos KSD (Kewajiban Segera Dibayar), laba ditahan, dana investasi terikat, dan PPAP (Penyisihan Penghapusan Aktiva Produktif) atau CKPN (Cadangan Kerugian Penurunan Nilai).

Kata Kunci: PER (Profit Equalization Reserve), Akad mudharabah.

Syahril Barokah Nurlaela. 2015. Persepsi manajemen bank Umum Syariah terhadap kemungkinan penerapan PER(Profit Equalization Reserve) ditinjau dari akuntansi bank syariah. Jurnal Nisbah(2): $132-144$.

\section{PENDAHULUAN}

Perkembangan bank syariah di Indonesia dimulai sejak berdirinya Bank Muamalat Indonesia atau lebih populer dengan sebutan BMI (Bank Muamalat Indonesia) tahun 1992 (Yasni, 2007). Dalam lima tahun terakhir aset perbankan syariah mencapai $\pm 46,89 \%$. Total aset perbankan syariah per Desember 2014 mencapai Rp 204.961 triliun. Market share perbankan syariah mencapai $\pm 4,9 \%$ dari total aset perbankan dengan jumlah rekening mencapai 13 juta rekening nasabah (Direktorat Perbankan Syariah, 2014). Data ini menunjukkan bahwa fungsi intermediasi perbankan syariah untuk menggerakan perekenomian sangat besar dan industri keuangan syariah pun menjadi semakin berkembang. Keuangan syariah di Indonesia diharapkan memiliki dinamika yang cepat dan mampu menjadi pendorong ekonomi global. Hal ini yang menjadi acuan bank agar lebih gigih dalam meningkatkan pangsa perbankan syariah nasional yang semakin ketat.

Pertumbuhan perbankan syariah diikuti dengan bertambahnya jumlah jaringan kantor perbankan syariah yang terdiri dari 12 Bank Umum Syariah (BUS) dan 22 Unit Usaha Syariah (UUS), dan pada Desember 2014 tumbuh sebesar 7,89 persen (yoy). Hal tersebut merupakan sedikit gambaran mengenai kondisi bank syariah saat ini. Dengan perkembangan yang begitu signifikan, perbankan syariah memiliki kebutuhan akan sebuah kebijakan untuk membantu mengintegrasikan keuangan syariah dalam sistem keuangan nasional dan global (Nurfuadi, 2014). Berikut grafik yang menunjukkan data tersebut:

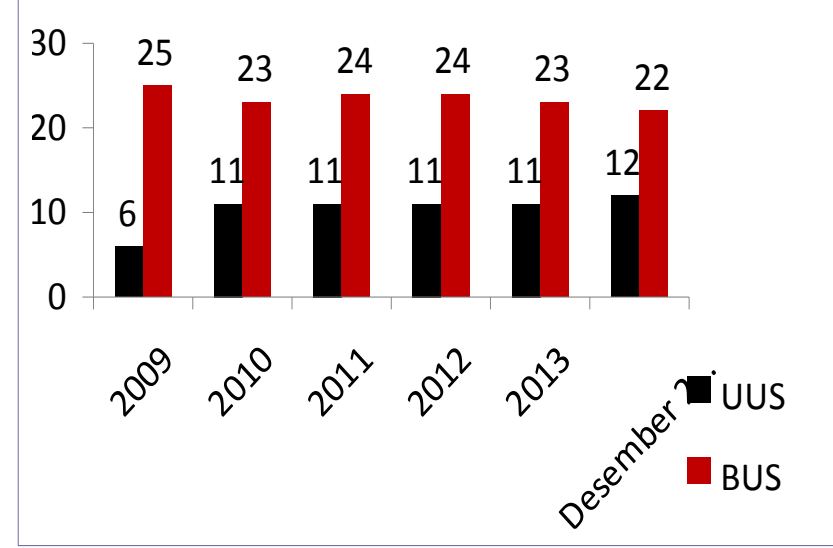

Gambar 1. Data Statistik Perbankan Syariah bulan Desember 2014

Sumber: situs www.ojk.go.id

Bank Syariah sebagai lembaga intermediasi, melakukan penghimpunan dan penyaluran dana dengan menggunakan prinsip kehati-hatian yang berdasarkan syariat Islam. Praktik bank syariah yang didasari "Intermediary Fuction" dimana keuntungan yang diperoleh bank syariah langsung disalurkan kepada nasabah penyimpan (Trihantana, 2015). Perolehan keuntungan atau pengembalian hasil pada bank syariah bersifat tidak pasti dan tidak tetap (fluktuatif). Upaya bank syariah dalam memitigasi risiko bagi hasil dengan nasabahnya, bisa menggunakan instrumen PER (Profit Equalization Reserve) yaitu sebuah cadangan yang dibuat oleh bank syariah dengan mengambil alih jumlah tertentu dari laba mudharabah, sebelum mengalokasikan ke porsi mudharib. Oleh karenanya, cadangan dana bisa digunakan ketika bagi hasil pembiayaan turun. Sehingga bank dapat mempertahankan 
tingkat tertentu dari laba atas investasi untuk kepentingan pemegang rekening investasi dan pemilik modal (Sundararajan, 2005). Keuntungan atau dana cadangan pada akad mudharabah tersebut akan dikelola oleh bank yang telah disepakati nasabah dan selanjutnya akan dimasukan ke dalam akuntansi bank syariah. Namun, di Indonesia dana cadangan (PER) belum ada pedoman akuntansi perbankan syariah Indonesia tentang pencatatan PER pada sistem akuntansi bank syariah baik dari BI (Bank Indonesia) maupun 0JK (Otoritas Jasa Keuangan).

\section{MATERI DAN METODE}

\section{Metode Penelitian}

Penelitian ini menggunakan jenis data deskriptif kualitatif. Penelitian dekriptif kualitatif merupakan penelitian pada situasi dimana peneliti memiliki pengetahuan atau pengalaman yang terbatas tentang isu yang diangkat dalam penelitian (Mansoer, 2004:16).

Obyek penelitian adalah PER (Profit Equalization Reserve), dengan fokus penelitian yaitu tentang pencatatan akuntansi pada Bank Muamalat dan Bank Syariah Mandiri Cabang Bogor.

Penelitian ini dilakukan untuk mengetahui persepsi manajemen bank umum syariah terhadap kemungkinan penerapan PER (Profit Equalization Reserve) ditinjau dari sisi akuntansi bank syariah, yang digunakan untuk menjaga stabilitas dan akuntabilitas keuangan pada bank syariah.

\section{Jenis dan Sumber Data}

Data yang diperoleh dalam melakukan penelitian bersumber dari :

1. Data primer, yakni data-data utama yang diperoleh dari hasil interview atau wawancara dan kuesioner yang ditujukan kepada Kepala Cabang dan Accounting pada Bank Muamalat dan Bank Syariah Mandiri Cabang Bogor.

2. Data primer, yakni data-data utama yang diperoleh dari hasil interview atau wawancara dan kuesioner yang ditujukan kepada Kepala Cabang dan Accounting pada Bank Muamalat dan Bank Syariah Mandiri Cabang Bogor.

3. Data sekunder, yakni data pendukung yang diperoleh melalui dokumentasi dari berbagai literature baik textbook, majalah, koran, internet dan yang memiliki keterkaitan dengan penelitian ini.

\section{Teknik Pengumpulan Data}

Teknik pengumpulan data dalam penelitian ini adalah:

1. Teknik Analisis Dokumen

Penelitian ini dilakukan dengan cara mengambil dan menganalisa datadata PER (Profit Equalization Reserve) pada Bank Muamalat dan Bank Syariah Mandiri Cabang Bogor.

2. Teknik Wawancara

Penelitian ini dilakukan melalui proses tanya jawab atau interview langsung kepada manajemen bank umum syariah mengenai penerapan PER (Profit Equalization Reserve) ditinjau dari sisi akuntansi bank syariah.

3. Teknik Kepustakaan

Penelitian ini dilakukan dengan membaca literatur-literatur PER (Profit Equalization Reserve), akuntansi bank syariah dan kepustakaan lainnya guna penyusunan landasan teori yakni mengambil data-data yang berkaitan dengan penelitian dari sumbersumber referensi seperti dari buku, majalah, artikel, surat kabar dan sebagainya

\section{Teknik Analisis Data}

Teknik analisis data yang dilakukan dalam penelitian ini menggunakan model Miles dan Huberman serta pengujian keabsahan dengan triangulasi data, adapun tahapan analisisnya adalah sebagai berikut:

\section{Model Miles dan Huberman}


Dalam menganalisis data, peneliti akan melakukan analisis data dilapangan yaitu pada saat mencari dan menyusun secara sistematis data yang diperoleh dari hasil wawancara, catatan lapangan, serta dokumentasi. Salah satu analisis data dilapangan yang digunakan yaitu model Miles dan Huberman (Sugiyono, 2011:246). Aktivitas analisis data yang akan dilakukan yaitu data reduction, data display, dan conclusion drawing. Berikut gambar alur analisis data yang akan dilakukan:

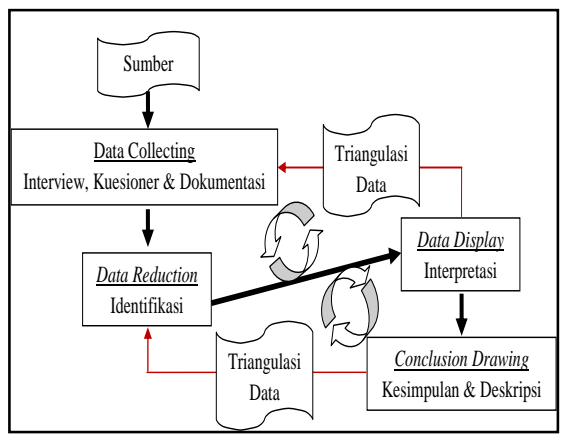

Gambar 2. Modifikasi Model Miles dan Huberman

Sumber: Modifikasi dari berbagai macam sumber 2015

\section{a. Data Reduction (Reduksi Data)}

Pada tahap reduksi data, peneliti mengidentifikasi data tentang PER (Profit Equalization Ratio) dan pencatatannya pada akuntansi bank syariah, baik melalui interview dan kuesioner yang ditujukan kepada kepala cabang dan accounting, serta analisis dokumen. Setelah data diperoleh, peneliti akan menyusun secara rinci dan lengkap serta mereduksi data-data tersebut. Mereduksi maksudnya menghilangkan atau membuang datadata yang tidak relevan dengan judul penelitian agar memudahkan dalam penyusunan laporan penelitian. Selanjutnya dirangkum dan disusun data-data yang relevan dengan masalah yang diteliti, agar data yang disajikan lebih sederhana (Moleong, 2006).

\section{b. Data Display (Penyajian Data)}

Pada tahap ini, peneliti menyajikan data hasil penelitian dengan cara menginterpretasikan data-data yang telah direduksi ke dalam bentuk teks naratif. Penyajian data dilakukan untuk melihat hasil penelitian yang telah dilakukan mengenai persepsi bank umum syariah terhadap kemungkinan penerapan PER (Profit Equalization Reserve) ditinjau dari sisi akuntansi bank syariah.

\section{c. Conclusion Drawing (Penarikan Kesimpulan)}

Berdasarkan hasil reduksi dan penyajian data, tahap selanjutnya adalah membuat kesimpulan dengan disertai bukti data yang benar dalam bentuk deskripsi atau gambaran obyek penelitian yaitu PER (Profit Equalization Reserve), dengan fokus penelitiannya adalah tentang pencatatan akuntansi pada Bank Muamalat dan Bank Syariah Mandiri Cabang Bogor. Dengan demikian, maka selama berlangsungnya penelitian, proses penarikan kesimpulan akan selalu diverifikasi. Kegiatan analisis data yang dilakukan, merupakan kegiatan yang saling berhubungan dan berlangsung secara terus-menerus selama pelaksanaan penelitian. tentang pencatatan akuntansi pada Bank Muamalat dan Bank Syariah Mandiri Cabang Bogor. Dengan demikian, maka selama berlangsungnya penelitian, proses penarikan kesimpulan akan selalu diverifikasi. Kegiatan analisis data yang dilakukan, merupakan kegiatan yang saling berhubungan dan berlangsung secara terus-menerus selama pelaksanaan penelitian.

\section{Pengujian Keabsahan Data}


Pada penelitian ini setelah semua data diperoleh, peneliti akan menguji validitas dan realibilitas informasi. Pengujian keabsahan data akan dilakukan dengan menggunakan triangulasi data (Data Triangulation), yaitu menggunakan sejumlah sumber data dalam penelitian (Denzin \& Lincoln, 1997).

Bungin (2007), triangulasi data dilakukan dengan mengecek data yang telah diperoleh dari beberapa sumber. Tujuannya adalah untuk mengetahui seberapa jauh data yang telah diperoleh sesuai dengan apa yang diberikan oleh pemberi data (Sugiyono, 2008). Tahap pada triangulasi data (Data Triangulation) ini, peneliti akan mencocokkan data hasil pengamatan dari kepala cabang, accounting dan dokumendokumen terkait agar hasil penelitian tentang persepsi bank umum syariah terhadap kemungkinan penerapan PER (Profit Equalization Reserve) ditinjau dari sisi akuntansi bank syariah menjadi lebih akurat.

\section{HASIL DAN PEMBAHASAN}

\section{Persepsi Manajemen Bank Umum} Syariah Terhadap Kemungkinan Penerapan PER (Profit Equalization Reserve) Ditinjau Dari Sisi Akuntansi Bank Syariah

Berikut adalah hasil wawancara yang dilakukan oleh peneliti merujuk pada pertanyaan penelitian yaitu sebagai berikut:

a. Persepsi Manajemen Bank Umum Syariah Terhadap Kemungkinan Penerapan PER (Profit Equalization Reserve)

Hasil penelitian yang telah dilaksanakan pada Bank Muamalat Indonesia (BMI) dan Bank Syariah Mandiri (BSM) Cabang Bogor mengenai persepsi manajemen bank umum syariah terhadap kemungkinan penerapan PER, yaitu bahwa kedua bank ini siap untuk menerapkan PER jika memang diperlukan dan ada undang-undang yang mengharuskan untuk menggunakan instrumen PER.

Dengan adanya instrumen tersebut, memudahkan bank syariah untuk bersaing dengan bank konvensional dan mampu menjaga daya saing imbal hasil pada perbankan syariah, serta modal bank pun akan terjaga dengan baik dan optimal.

Cadangan dana atau PER ini bisa digunakan ketika bagi hasil pembiayaan turun, sehingga minat deposan dapat terjaga karena bagi hasil yang turun bisa ditutupi dengan dana cadangan tersebut. Pada praktiknya BMI dan BSM dalam memperoleh keuntungan dari akad mudharabah, keuntungan yang diperoleh setiap bulannya tidaklah sama, tergantung keberhasilan usaha yang dikelola.

Hal tersebut mempengaruhi jumlah keuntungan yang dibagikan kepada nasabah. Namun menurut pendapat para responden yaitu karyawan BMI dan BSM, apabila PER diterapkan akan membutuhkan biaya yang besar sehingga pengeluaran bank akan bertambah atau pendapatan bank menjadi berkurang, selain itu ada kekhawatiran dari pihak bank yakni akan terganggunya stabilitas usaha yang dijalankan oleh BMI dan BSM itu sendiri.

Responden BMI yang bekerja sebagai back office menyatakan ada beberapa kerugian jika PER diterapkan pada bank syariah, diantaranya PER mungkin hanya menguntungkan satu pihak saja yaitu nasabah bermodal besar, dan jika ternyata pada pembiayaan mudharabah keuntungan dibawah ekspektasi terjadi terus-menerus, maka pendapatan bank dan bahkan hak karyawan bank untuk mendapatkan bonus atau insentif dari sebagian laba menjadi semakin kecil porsinya.

Berdasarkan analisis yang dilakukan oleh peneliti terhadap pernyataan dari beberapa responden mengenai pendapatan bank menjadi berkurang karena 
diterapkannya PER, dirasa kurang tepat. Pada praktiknya, jika PER diterapkan kemudian terjadi risiko pada akad mudharabah atau bagi hasil yang ternyata dibawah ekspektasi, maka bank tidak boleh menutupi kerugian tersebut dengan pendapatan bank.

Cara mitigasi seperti itu kurang sesuai dengan Fatwa DSN-MUI nomor: 87/DSNMUI/XII/2012 tentang metode perataan penghasilan (income smoothing) dana pihak ketiga yaitu "kebijakan metode perataan penghasilan tidak PER dengan dana atau pendapatan bank, karena hal ini jelas-jelas mengandung unsur riba. Maksud dengan unsur riba tersebut, yakni porsi bagi hasil yang seharusnya menjadi hak mudharib atau bank digunakan untuk menutupi bagi hasil yang ternyata di bawah ekspektasi atau pendapatan dari sumber lain yang tidak ada hubungannya dengan transaksi yang dibiayai.

Ketentuan mengenai PER dalam Fatwa DSN-MUI tersebut, sudah jelas menerangkan bahwa bank tidak boleh serta merta memberikan imbal hasil yang tidak sesuai dengan hasil nyata. Maka bank tidak boleh menutup kerugian. Mitigasi risiko pada akad mudharabah yakni pada saat keuntungan dibawah ekspektasi, kemudian menggunakan dana atau pendapatan bank. Hal ini termasuk pada riba qardl, seperti yang terdapat pada hadist berikut ini:

Imam Bukhari meriwayatkan sebuah hadist dari Abu Burdah bin Musa; ia berkata, "Suatu ketika, aku mengunjungi Madinah. Lalu aku berjumpa dengan Abdullah bin Salam. Lantas orang ini berkata kepadaku: 'Sesungguhnya engkau berada di suatu tempat yang di sana praktek riba telah merajalela. Apabila engkau memberikan pinjaman

kepada seseorang lalu ia memberikan hadiah kepadamu berupa rumput kering, gandum atau makanan ternak, maka janganlah diterima. Sebab, pemberian tersebut adalah riba". (HR. Imam Bukhari)

Imam Bukhari dalam "Kitab Tarikh" nya, meriwayatkan sebuah Hadist dari Anas ra. bahwa Rasulullah SAW telah bersabda, "Bila ada yang memberikan pinjaman (uang maupun barang), maka janganlah ia menerima hadiah (dari yang meminjamkannya)". (HR. Imam Bukhari)

Hadist diatas dapat dianalogikan pada praktik penerapan PER, yakni jika bank berpendapat bahwa ketika keuntungan dibawah ekspektasi, maka imbal hasil akan tetap rata, karena akan di backup oleh pendapatan atau dana bank. Hal ini tentu terdapat riba terselubung antara bank dengan deposan, dan deposan pun akan menerima serta menikmati tambahan atau riba tersebut dari bank. Praktik seperti ini sangat dilarang, terutama dalam transaksi yang berdasarkan syariat Islam. Terdapat pula dalam firman Allah SWT:

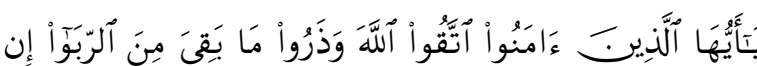

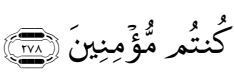

Artinya: "hai orang-orang yang beriman, bertakwalah kepada Allah dan tinggalkan sisa riba (yang belum dipungut) jika kamu orang-orang yang beriman." (QS. Al-Baqarah: 278)

Maksud dari ayat di atas, bahwa dengan jelas dan tegas mengharamkan apapun jenis tambahan yang diambil dari segala macam usaha, karena seorang Muslim wajib menjauhi praktik riba, apapun jenis riba itu, dan berapapun kuantitas riba yang diambilnya. Seluruhnya adalah haram dilakukan oleh seorang Muslim.

Selain itu, pernyataan dari responden mengenai pengeluaran bank akan bertambah dikarenakan bank harus menanggung risiko ketika keuntungan dibawah ekspektasi. Pernyataan ini seolaholah bank hanya menutupi kerugian pada satu pembiayaan yaitu pada akad mudharabah saja, maka bank secara tidak langsung menggunakan hak bank sendiri dalam memperoleh keuntungan. Hal ini terdapat dalam firman Allah SWT: 


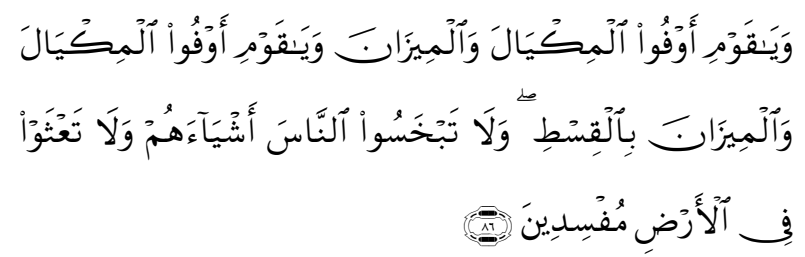

Artinya: Dan Syu'aib berkata: "Hai kaumku, cukupkanlah takaran dan timbangan dengan adil, dan janganlah kamu merugikan manusia terhadap hak-hak mereka dan janganlah kamu membuat kejahatan di muka bumi dengan membuat kerusakan."(QS. Huud: 85)

Ayat di atas menjelaskan bahwa Allah SWT melarang hambanya untuk merugikan manusia pada hak-haknya. Terkait dengan masalah tersebut, bank secara tidak langsung menutup bagi hasil yang turun dengan mengurangi hak nya dalam memperoleh keuntungan serta hal ini akan merugikan bank itu sendiri dan bahkan akan merugikan para karyawan dalam memperoleh gaji, insentif dan lain-lain.

Fatwa DSN-MUI nomor: 87/DSNMUI/XII/2012 tentang metode perataan penghasilan (income smoothing) dana pihak ketiga, yaitu "Dalam hal akad Mudharabah Muqayyadah, dana cadangan (PER) dbentuk melalui penyisihan keuntungan hak nasabah yang melebihi tingkat imbalan yang diproyeksikan setelah dibagi hasilkan dengan izin nasbah DPK". Dari ketentuan tersebut, dijelaskan bahwa dana cadangan (PER) hanya dibentuk oleh bank syariah dari penyisihan laba yang melebihi tingkat imbal hasil yang diproyeksikan untuk penyesuaian bagi hasil dana mudharabah. Selain itu, pembentukan PER harus disepakati para pihak atau dengan izin nasabah.

Saat ini, return yang diperoleh dalam pembagian usaha bank syariah dengan deposan yang dilakukan setiap akhir bulan, perolehan keuntungan pada akad mudharabah bersifat tidak tetap (fluktuatif). Menurut penuturan responden BSM selaku back office apabila bank syariah mengalami kerugian maka nasabah tetap terlindungi melalui Lembaga Penjaminan Simpanan (LPS). Oleh karenanya, dengan tidak diterapkannya PER, dana nasabah akan terlindungi oleh LPS.

Berdasarkan analisis yang dilakukan oleh peneliti, pernyataan yang dituturkan oleh responden BSM tersebut kurang sesuai dengan tugas LPS, karena LPS hanya membayar atau mengganti kerugian ketika izin usaha bank dicabut atau bank dilikuidasi (Wahyudi, 2010: 102).

Sistem operasional yang berdasarkan prinsip bagi hasil, bank syariah memiliki kekuatan tersendiri yang berbeda dari bank konvensional. Perbedaan tersebut terlihat bahwa dalam sistem bagi hasil terkandung dimensi keadilan, terutama pada kegiatan penghimpunan dana berprinsip mudharabah. Menurut responden BMI selaku back office, dalam melakukan penghimpunan dana dalam bank konvensional dan bank syariah memiliki perbedaan paradigma yang mendasar yaitu:
a.Tujuan masyarakat menyerahkan dananya pada bank konvensional dimaksudkan untuk menabung dan mengamankan dananya serta mengharapkan bunga dari dana yang disimpan tersebut.

b. Tujuan masyarakat menyalurkan dananya pada bank syariah adalah untuk diinvestasikan dalam berbagai pembiayaan. Apabila memperoleh laba akan dibagi sesuai nisbah bagi hasil, adapun apabila menderita kerugian maka masyarakat ikut menanggung kerugian tersebut.

Perbedaan paradigma yang dituturkan oleh responden BMI tersebut, terlihat dari mekanisme deposito konvensional, dimana deposan sudah dipatok bunga sehingga bank harus memberikan return sebesar bunga yang ditetapkan pada awal pembukaan rekening, adapun untuk deposito mudharabah bank syariah tidak bisa dipastikan ketetapan return yang akan diperoleh deposan pada akhir bulan. Penetapan nisbah pada bank syariah pun berbentuk rasio dan bukan dalam bentuk 
persentase seperti yang terdapat di bank konvensional, karena hal tersebut digunakan untuk menghindari ketidakpastian. Porsi deposan dalam bagi hasil ini adalah lebih besar dari porsi bank. Hal ini disebabkan karena risiko yang ditanggung deposan lebih besar sebagai pemilik modal dibanding bank sebagai mudharib.

Responden BMI dan BSM, menjelaskan hasil survei lima tahun terakhir ini bahwa nasabah lebih merasa aman menyimpan dana mereka pada bank syariah di tengah keadaan ekonomi yang tidak menentu. Hal ini menunjukkan bahwa dengan tidak diterapkannya instrumen PER bank syariah mampu mempertahankan usahanya serta menjaga minat deposan khususnya pada akad mudhrabah dengan metode bagi hasil yang sudah ada.

Berdasarkan analisis peneliti, dari pernyataan responden tersebut bank syariah harus cermat dalam menjaga minat deposan untuk menyimpan dananya di bank syariah. Bank perlu mengkaji lebih dalam mengenai PER, karena PER dalam tinjauan fiqh boleh diterapkan pada bank syariah, karena mengandung maslahat. Jika dilihat dari tingkatan maslahah, PER berada pada maslahah tingkat tiga yaitu maslahah tahsiniyat, dimana keberadaan instrumen PER (Profit Equalization Reserve) ini merupakan pendukung dan pelengkap yang digunakan dalam memitigasi risiko yang bertujuan untuk mempertahankan tingkat pengembalian (Nurfuadi, 2014).

\section{a. PER (Profit Equalization Reserve) Ditinjau Dari Sisi Akuntansi Bank Syariah}

Instrumen PER (Profit Equalization Reserve) merupakan cadangan yang dibuat oleh bank syariah dengan mengambil alih jumlah tertentu dari laba mudharabah, sebelum mengalokasikan ke porsi mudharib. Bank Muamalat Indonesia (BMI) dan Bank Syariah Mandiri (BSM) mengasumsikan bahwa PER bisa disimpan atau dicatat pada sistem akuntansi bank syariah yaitu di pos kewajiban segera dibayar (KSD), laba ditahan, dan dana investasi tidak terikat. Penjelasan mengenai PER ditinjau dari sisi akuntansi bank syariah adalah sebagai berikut:

1) Asumsi Pencatatan PER (Profit Equalization Reserve) pada Pos Kewajiban Segera Dibayar (KSD)

Menurut penuturan responden BMI selaku back office, PER dapat disimpan pada pos Kewajiban Segera Dibayar. Kewajiban segera adalah kewajiban bank kepada pihak lain yang sifatnya wajib segera dibayarkan (KSD) sesuai perintah pemberi amanat atau perjanjian yang ditetapkan sebelumnya. (PSAK 31 Akuntansi Perbankan Syariah, Paragraf 11). Adapun kewajiban segera terdiri dari:

a.Penerimaan pajak termasuk potongan pajak yang masih harus disetor. Kewajiban pajak untuk transaksi mata uang asing dibukukan dalam rupiah dengan menggunakan kurs yang ditetapkan oleh Menteri Keuangan pada saat pemotongan (pajak terutang).

b. Kewajiban yang sudah jatuh tempo namun belum ditarik seperti deposito mudharabah, setoran jaminan, bagi hasil yang belum diambil shahibul maal.

c.Dana transfer atau kiriman uang masuk dan keluar

d. Saldo rekening tabungan dan giro yang sudah ditutup namun belum diambil oleh pemilik rekening.

e.Komponen-komponen diatas apabila jumlahnya material dapat dikelompokan dalam pos tersendiri.

Responden BSM selaku back office menyatakan PER memungkinkan untuk disimpan atau dicatat pada pos kewajiban segera. Melalui PER, bank dapat memenuhi kewajiban kepada para nasabahnya dan juga dapat menjaga modal bank dengan baik. Dari pernyataan responden tersebut, ada beberapa kelemahan jika PER ditempatkan di pos KSD, yaitu cadangan atau PER tidak dapat dikelola kembali dan 
tidak menimbulkan kewajiban pembayaran bagi hasil atau bonus, karena dana untuk KSD harus segera habis. Adapun transaksi kewajiban segera ini diakui pada saat timbulnya kewajiban dari pemberi amanat, baik nasabah masyarakat (nasabah bukan bank) maupun dari bank lain dan PER ini segera disajikan di neraca sebesar jumlah kewajiban bank yang wajib segera dibayarkan (KSD).

2) Asumsi Pencatatan PER (Profit Equalization Reserve) pada Pos Cadangan Umum

PER merupakan cadangan yang bisa difungsikan untuk menutup kerugian bagi hasil pada waktu yang akan datang. Bank perlu memupuk dana untuk memperbesar jaminan terhadap kewajiban dalam melakukan tugas dan usahanya, fungsi PER juga memungkinkan untuk menjamin kelangsungan usaha bank. Menurut penuturan responden BSM selaku back office, yakni PER bisa saja disimpan pada pos cadangan umum yang merupakan penyisihan dari laba ditahan atau dari laba bersih setelah dikurangi pajak, namun harus berdasarkan RUPS (Rapat Umum Pemegang Saham), apabila hasil RUPS telah diputuskan dan para pemegang saham telah menyetujui penyisihan sebagian laba bersih dari PER, maka dana cadangan tersebut bisa dimasukan ke dalam pos cadangan umum.

Jika PER disimpan pada pos cadangan umum, maka kemampuan pemenuhan dana dari intern akan semakin besar dan hal ini menjadikan posisi finansial bank akan kuat, karena tidak bergantung terhadap dana ekstern. Alasan bank dalam melakukan pencadangan, biasanya karena perlindungan pada posisi modal kerja dan kemungkinan kerugian. Oleh karenanya PER diasumsikan bisa disimpan pada pos cadangan umum yang merupakan penyisihan laba ditahan, karena dapat mengatasi kemungkinan terjadi kerugian di masa yang akan datang khususnya pada pembiayaan akad mudharabah pada bank syariah.

Cadangan umum pada dasarnya terbentuk dari akumulasi laba yang dipindahkan akun ikhtisar laba-rugi (income summary). Begitu saldo laba ditutup ke cadangan umum, sebenarnya saldo laba tersebut telah lebur menjadi elemen modal pemegang saham yang sah.

Seperti juga modal setoran, cadangan umum menunjukkan sejumlah hak atas seluruh jumlah rupiah aset bukan hak atas jenis aset tertentu. Bank mempunyai hak untuk mengelola dana cadangan atau PER dalam meningkatkan usaha bank, namun tetap proporsi laba menjadi hak penuh pemilik modal. Oleh karenanya ada aturan dan proporsi yang harus disepakati bersama antara pihak-pihak yang terlibat. Dengan jalan menabulasi kebutuhan, pemilik modal dapat mengambil haknya sesuai dengan ketentuan yang disepakati.

Namun, dari hasil pengamatan dari pernyataan responden mengenai PER disimpan pada pos dana cadangan umum bank syariah yaitu kurang tepat. Dana cadangan umum berbeda dengan dana PER. Cadangan umum dipergunakan untuk menutup kerugian yang mungkin terjadi terhadap modal bank. Bank perlu memupuk cadangan umum untuk memperbesar jaminan terhadap kewajibannya dalam melakukan tugas dan usahanya. Cadangan umum juga berfungsi untuk menjamin kelangsungan usaha bank. Bank Indonesia mengatur tentang besar cadangan umum bank pada Peraturan Bank Indonesia nomor: 10/15/PBI/2008 tentang kewajiban penyediaan modal minimum bank umum.

Adapun dana cadangan atau PER adalah sebuah cadangan yang dibuat oleh bank syariah dengan mengambil alih jumlah tertentu dari laba mudharabah, sebelum mengalokasikan porsi mudharib. Dengan demikian, bank dapat mempertahankan tingkat tertentu dari laba atas investasi untuk kepentingan pemegang rekening investasi dan pemilik modal. Selain itu, dengan menggunakan PER, bank dapat mengoptimalkan jumlah laba yang akan dibagikan kepada sahibul maal dengan mudharib dengan rata. Hal ini sesuai dengan fatwa Dewan Syariah Nasional 
nomor: 87/DSN-MUII/2012 tentang metode perataan penghasilan (income smoothing) dana pihak ketiga yakni "(Profit Equalization Reserve) adalah dana cadangan yang dibentuk oleh LKS yang berasal dari penyisihan laba LKS yang melebihi tingkat imbalan atau hasil yang diproyeksikan untuk penyesuaian bagi hasil dana mudharabah (muthlaqah); dan dalam hal simpanan dana nasabah menggunakan akad mudharabah muqayadah, jika disepakati para pihak, pembentukan cadangan penyesuaian bagi hasil dapat pula berasal dari penyisihan keuntungan nasabah yang melebihi tingkat bagi hasil yang diproyeksikan".

Dana cadangan atau PER, pada neraca akuntansi syariah sangatlah berbeda dengan neraca konvensional. Perbedaannya yakni pada bank konvensional, proporsi tanpa memerlukan pembagian dan penahanan harta dari laba, sepenuhnya hak bank sebagai pengelola tanpa memerlukan persetujuan terlebih dahulu dari IAH (Invesment Account Holder) sebagai pemodal untuk membagikannya. Padahal ketika bank telah memperhitungkan keuntungan, pada hakekatnya laba tersebut adalah hak milik seluruh IAH yang mengharuskan bank meminta izin untuk menahan dananya. Hal ini sesuai dengan firman Allah SWT:

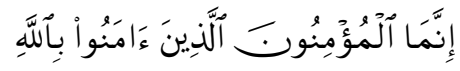

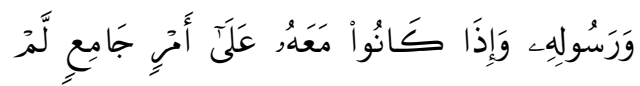

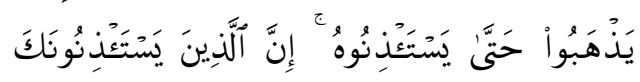

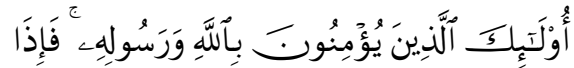

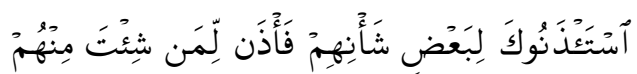

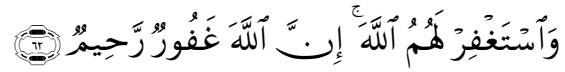

Artinya: "Sesungguhnya yang sebenar-benar orang mukmin ialah orang-orang yang beriman kepada Allah dan Rasul-Nya, dan apabila mereka berada bersama-sama Rasulullah dalam sesuatu urusan yang memerlukan pertemuan, mereka tidak meninggalkan (Rasulullah) sebelum meminta izin kepadanya. Sesungguhnya orang-orang yang meminta izin kepadamu(Muhammad) mereka Itulah orang-orang yang beriman kepada Allah dan Rasul-Nya, Maka apabila mereka meminta izin kepadamu karena sesuatu keperluan, berilah izin kepada siapa yang kamu kehendaki di antara mereka, dan mohonkanlah ampunan untuk mereka kepada Allah. Sesungguhnya Allah Maha Pengampun lagi Maha Penyayang." (QS. An-Nuur: 62)

Sabda Rasulullah SAW:

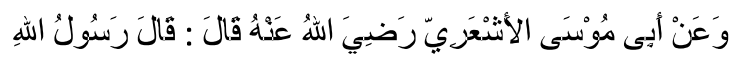

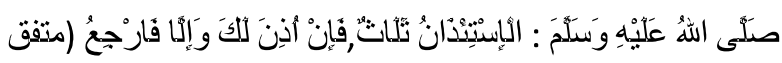

$$
\begin{aligned}
& \text { عليه) }
\end{aligned}
$$

Dari ayat dan hadist di atas dijelaskan bahwa kita dianjurkan untuk meminta izin terlebih dahulu sebelum menggunakan hak milik orang lain, sama halnya dengan instrumen PER yang harus memperoleh izin terlebih dahulu dari nasabah atau pemegang rekening investasi sebelum menciptakan rekening PER, hal ini dilakukan agar terjadi keadilan diantara semua pihak, baik pihak nasabah pemegang rekening investasi atau pihak bank syariah.

3) Asumsi Pencatatan PER (Profit Equalization Reserve) pada Pos Dana Investasi Tidak Terikat

PER (Profit Equalization Reserve) diasumsikan bisa disimpan pada pos dana 
investasi tidak terikat. Dengan disimpannya PER pada dana investasi tidak terikat, maka PER dapat diinvestasikan kembali (reinvestasi) oleh IAH sebagai shahibul maal dan dikelola oleh bank sebagai mudharib. Dalam hal investasi tidak terikat untuk diinvestasikan kembali, bank harus meminta izin kepada IAH atas dana cadangan tersebut untuk membiarkan dananya tetap berada di bank. Sehingga dana tersebut menjadi tambahan atas dana IAH lain yang akan berinvestasi di bank syariah atau bisa disalurkan kepada nasabah pembiayaan yang membutuhkan. Hal ini sesuai dengan firman Allah SWT:

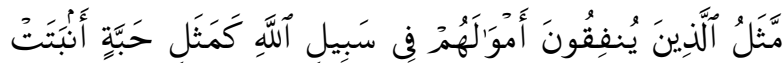
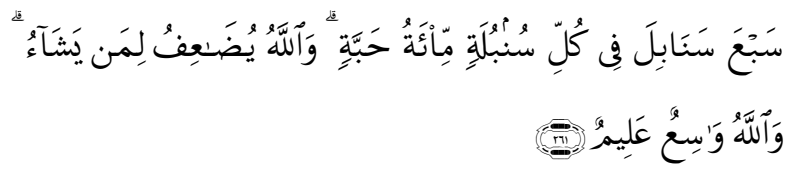

Artinya: "Perumpamaan orang -orang yang menafkahkan hartanya di jalan Allah adalah serupa dengan sebutir benih yang menumbuhkan tujuh tangkai, pada tiap-tiap tangkai:tumbuh seratus biji. Allah melipat gandakan (ganjaran) bagi siapa yang Dia kehendaki. Dan Allah Maha Luas (karunia-Nya) lagi Maha Mengetahui."(QS. AlBaqarah: 261)

Ayat diatas menjelaskan bahwa, jika kita berinvestasi dimulai dengan (sebutir benih), maka akan tumbuh menjadi tujuh bulir dan akhirnya menjadi tujuh ratus biji. Al-Qur'an telah memberikan panduan investasi (walaupun dalam hal ini adalah infaq), namun bila banyak orang yang menginvestasikan hartanya, maka akan menolong ratusan bahkan ribuan orang miskin dapat berusaha dan menjadi produktif.

Jika dana cadangan atau PER didistribusikan untuk investasi IAH lain, maka dana cadangan atau PER semakin besar. Hal ini perlu diperhatikan bahwa ketika dana PER diinvestasikan kembali, maka bank harus cermat dalam memilih investasi yang akan dijalankan, yakni dengan tingkat risiko yang rendah atau minim. Sebab semakin besar dana yang disetor oleh investor, maka semakin besar pula porsi dari laba yang IAH terima. Demikian pula, apabila terjadi kerugian, maka semakin besar pula tanggungan yang akan diterima.

Investasi tidak terikat ini tidak dapat dikategorikan sebagai kewajiban dan tidak pula dikategorikan sebagai ekuitas, karena sesuai prinsip syariah mudharabah. Apabila terdapat kerugian yang bukan kelalaian mudharib, maka kerugian tersebut menjadi tanggungan pemilik dana (shahibul maal). Oleh karena itu, dana tersebut tidak harus dikembalikan oleh mudharib seluruhnya (100\%) namun, dikembalikan setelah dikurangi dengan kerugian yang ditanggung oleh pengelola dana mudharabah tersebut.

Bank syariah pada investasi terikat mempunyai hak untuk mengelola dana cadangan atau PER dan menginvestasikan dana yang diterima dengan atau tanpa batasan seperti mengenai tempat, cara atau obyek investasi, namun tetap harus dengan izin pemilik dana (IAH). Investasi tidak terikat merupakan salah satu unsur neraca dimana hal tersebut sesuai dengan prinsip syariah yang memberikan hak kepada bank syariah untuk mengelola dan menginvestasikan dana, termasuk untuk mencampur dana dengan dana lainnya. Pemilik dana (shahibul maal) memperoleh bagian atas keuntungan sesuai kesepakatan dan menerima kerugian berdasarkan jumlah dana dari masing-masing pihak.

Pembagian hasil dana investasi tidak terikat dapat dibagikan dengan konsep bagi hasil atau bagi untung. Menurut responden BMI selaku back office, jika PER disimpan pada pos investasi tidak terikat, maka setiap pendapatan yang dihasilkan dari reinvestasi cadangan tersebut dialokasikan kembali ke PER masing-masing IAH dan bank syariah. Dengan demikian PER akan terus menerus berputar dan mungkin dana cadangan tersebut akan besar. Namun ada kemungkinan bisa dihentikan, yakni ketika ada permintaan deposan untuk menghentikan PER, karena tidak sesuai 
dengan yang diharapkan dan ketika terjadi likuidasi pada bank syariah.

4) Asumsi Pencatatan PER (Profit Equalization Reserve) pada Pos PPAP (Penyisihan Penghapusan Aktiva Produktif) atau CKPN (Cadangan Kerugian Penurunan Nilai)

PER diasumsikan bisa disimpan di pos PPAP (Penyisihan Penghapusan Aktiva Produktif) yang saat ini menjadi CKPN (Cadangan Kerugian Penurunan Nilai) yang mengacu pada PSAK 55 (Revisi 2011). Dilihat dari fungsinya, PER dan CKPN memiliki fungsi yang sama yaitu suatu instrumen cadangan untuk memitigasi kerugian pada usaha yang dijalankan oleh bank syariah dengan menyisihkan sebagian laba usahanya untuk menutupi risiko yang mungkin terjadi. Namun terdapat perbedaan antara PER dan CKPN, jika pada instrumen PER dana cadangan dialokasi lebih ke akad kerja sama dengan perolehan bagi hasil, adapun pada CKPN alokasi dana cadangannya dengan perolehan margin.

PPAP atau CKPN merupakan cadangan yang dibentuk oleh bank untuk memitigasi terjadinya risiko-risiko saat menghimpun dan menyalurkan dana dalam aktiva produktif. Besarnya penyisihan penghapusan aktiva produktif dibentuk sebesar persentasi tertentu dari nominal yang ada dan pengurangan dari masingmasing aktiva yang ada. Aktiva produktif berfungsi untuk memperoleh pendapatan atas dana yang disalurkan oleh bank. Namun demikian, penempatan dana dalam aktiva produktif juga memiliki risiko, yaitu risiko dana yang disalurkan tidak dapat kembali. Risiko atas penempatan dalam bentuk ini dapat menimbulkan kerugian bank. Oleh karenanya, agar usaha yang dijalankan bank lebih stabil dan perolehan laba yang diterima deposan pun optimal, maka PER memungkinkan untuk disimpan pada pos CKPN.

\section{KESIMPULAN DAN IMPLIKASI}

Berdasarkan hasil penelitian yang telah dilakukan dengan mengumpulkan datadata dan informasi dilapangan, dan disesuaikan dengan permasalahanpermasalahan yang dipaparkan sebelumnya, maka dapat dikemukakan beberapa kesimpulan mengenai Persepsi Manajemen Bank Umum Syariah Terhadap Kemungkinan Penerapan PER (Profit Equalization Reserve) ditinjau dari sisi akuntansi bank syariah diantaranya adalah: 1. Persepsi Manajemen Bank Umum Syariah (BUS) Bank Muamalat Indonesia (BMI) dan Bank Syariah Mandiri (BSM) cabang Bogor yaitu bahwa kedua bank ini siap untuk menerapkan PER jika memang diperlukan dan ada undangundang yang mengatur serta mengharuskan untuk menggunakan instrumen PER.

2. Ada beberapa kelebihan pada penerapan PER yaitu memudahkan bank syariah untuk bersaing dengan bank konvensional dan mampu menjaga daya saing imbal hasil pada perbankan syariah, serta modal bank pun akan terjaga dengan baik atau optimal. Adapun kelemahan pada penerapan PER, salah satunya adalah keuntungan hanya dirasakan oleh satu pihak saja yaitu nasabah bermodal besar. BMI dan BSM Cabang Bogor mengasumsikan pencatatan PER pada sistem akuntansi bank syariah yaitu bisa disimpan pada neraca pasiva di pos KSD (Kewajiban Segera Dibayar), laba ditahan, dana investasi tidak terikat, PPAP (Penyisihan Penghapusan Aktiva Produktif) atau CKPN (Cadangan Kerugian Penurunan Nilai). Pada pos KSD, cadangan atau PER tidak dapat dikelola kembali dan tidak menimbulkan kewajiban pembayaran bagi hasil atau bonus, karena dana untuk KSD harus segera habis. PER juga diasumsikan bisa disimpan pada pos cadangan umum, namun harus melalui RUPS terlebih dahulu, karena dapat mengatasi kemungkinan terjadi kerugian di masa yang akan datang, khususnya pada pembiayaan akad mudharabah pada bank syariah. Namun tidak semua deposan merupakan pemegang saham. Selain itu, PER bisa disimpan pada pos 
dana investasi tidak terikat, maka setiap pendapatan yang dihasilkan dari investasi PER dialokasikan kembali ke PER masing-masing IAH dan bank syariah. Adapun pada pos lain, PER diasumsikan bisa disimpan pada pos PPAP (Penyisihan Penghapusan Aktiva Produktif) atau CKPN (Cadangan Kerugian Penurunan Nilai), karena mempunyai fungsi yang sama yaitu mampu memitigasi risiko-risiko yang mungkin timbul pada usaha yang dijalankan oleh bank syariah.

3. Diperlukan sosialisasi dari Otoritas Jasa Keuangan (OJK) dan Bank Syariah kepada masyarakat mengenai metode bagi hasil PER agar dapat melihat konsep perbankan syariah yang sesungguhnya.

4. Otoritas Jasa Keuangan (OJK) diharapkan untuk membuat PAPSI (Pedoman Akuntansi Syariah Indonesia) mengenai metode pengakuan dana cadangan atau PER pada sistem akuntansi bank syariah.

\section{DAFTAR PUSTAKA}

Bungin, Burhan. 2010. Penelitian Kualitatif. Jakarta: Kencana Prenada Media Group.

Denzin \& Lincoln. 1997. Handbook of Qualitative Reasearch. Terjemahan Dariyatno, dkk. Yogyakarta: PT. Pustaka Pelajar.

Dewan Standar Akuntansi Keuangan. 2007. PSAK No. 105. Jakarta: Ikatan Akuntan Indonesia.

Mansoer. Faried Wijaya. 2004. Metode Penelitian. Jakarta: Universitas Terbuka.

Moleong, Lexy J. 2006. Metode Penelitian Kualitatif. Bandung: PT. Remaja Rosdakarya.

Nurfuadi, Muhammad Rofiudin. 2014. Penerapan Profit Equalization Reserve (PER) Perbankan Syariah Dalam Tinjauan Fiqih. Skripsi. Bogor: Universitas Djuanda.
Sundararajan. 2005. "Pengukuran Risiko, dan Pengungkapan Keuangan Islam dan Implikasi Bagi Hasil Account Investasi." Makalah yang dipresentasikan di Konferensi Internasional Keenam tentang Ekonomi Islam, Perbankan dan Keuangan, November 22-24, 2005. Jakarta-Indonesia.

Trihantana, Rully. 2015. Model Penerapan Profit Equalization Reserve (PER) pada Lembaga Keuangan Syariah di Indonesia. Bogor: Universitas Djuanda.

Wahyudi. 2010. Manajemen Risiko Bank Islam. Jakarta: PT. Salemba Empat.

Zuhri, Muhammad. 1996. Riba dalam alQuran dan Perbankan. Jakarta: PT. Raja Grafindo Persada.

\section{Sumber Internet:}

Direktorat Perbankan Syariah. 2014. Aset Perbankan Syariah Tahun 2014.

(http://www.bi.go.id/web/id/Statistik/S tatistik+Perbankan/Statistik+Perbanka $\underline{\text { n+Syariah) diakses pada tanggal } 20}$ November 2014.

Fatwa Dewan Syariah Nasional No. NO: 87/DSN-MUIIXII/2012 Tentang Metode Perataan Penghasilan (Income Smoothing)Dana Pihak Ketiga

(http://icmspecialist.com/Income_Smo othing_Dana_Pihak_Ketiga.pdf) diakses pada 20 Januari 2015.

Otoritas Jasa Keuangan. 2013. Surat Edaran CKPN. (http://www.ojk.go.id) diakses pada tanggal 19 Mei 2015. 